\title{
Effects of Impregnation with Tanalith-E on the Compression Strength of Some Woods
}

\author{
Hakan KESKİN ${ }^{1, *}$, Nihat DAĞLIOĞLU ${ }^{2}$ \\ ${ }^{1}$ Gazi University, Technology Faculty, Department of Wood Products Industrial Engineering, \\ 06500 Teknikokullar, Ankara - TURKEY \\ ${ }^{2}$ Gazi University, Industrial Arts Education Faculty, Department of Industrial Technology Education, \\ 06500 Beşevler, Ankara - TURKEY \\ (Received : 03.09.2016 ; Accepted : 02.11.2016)
}

\begin{abstract}
This study was performed to determine the effects of impregnation with Tanalith-E on compression strengths of Oriental beech (Fagus orientalis Lipsky), European oak (Quercus petraea Liebl.), Black walnut (Junglans nigra Lipsky), Lombardy poplar (Populus nigra Lipsky), Ash (Fraxinus exelsior Lipsky) and Scotch pine (Pinus sylvestris Lipsky) woods. For this aim, the wood samples were prepared according to TS 345 and impregnated with Tanalith-E by the method of the vacuum according to ASTM D 1413 and producers' definition. After impregnation process, compression strength was measured according to TS 2595. Consequently, compression strengths of wood un-impregnated were found higher (approximately 6.63\%) than impregnated with Tanalith-E wood materials. Accordingly, the highest values of compression strengths were obtained in impregnated Oriental beech and ash woods, whereas the lowest values were obtained in the Lombardy poplar wood.
\end{abstract}

Keywords : Compression strength, Tanalith E, impregnation, woods.

Öz

Bu çalışma, su bazlı Tanalith-E ile emprenye etmenin ağaç malzemelerin (Doğu kayını (Fagus orientalis Lipsky), Sapsız meşe (Quercus petraea Liebl.), Kara ceviz (Junglans nigra Lipsky), Kavak (Populus nigra Lipsky), Dişbudak (Fraxinus exelsior Lipsky), Sarıçam (Pinus sylvestris Lipsky)) basınç direncine etkilerini belirlemek amacıyla yapılmıştır. Bu maksatla; kayın, meşe, ceviz, kavak, dişbudak ve sarıçam odunlarından TS EN 345 esaslarına göre hazırlanan deney örnekleri Tanalith-E ile ASTM D 1413 esaslarına uyularak vakum yöntemi ile emprenye edilmiştir. Emprenye edildikten sonra basınç direnci değerleri TS 2595 standardı esaslarına göre belirlenmiştir. Sonuç olarak, emprenyesiz örneklerin emprenye edilmiş örneklere göre; basınç direnci değeri yaklaşık olarak \% 6.63 daha yüksek bulunmuştur. Tanalith-E ile emprenye edilmiş ağaç malzemelerin basınç direnci değerleri en yüksek kayın ve dişbudakta, en düşük değerler ise kavak odununda elde edilmiştir.

Anahtar Kelimeler : Basınç direnci, tanalith e, emprenye, ağaç malzemeler.

\section{INTRODUCTION}

Preserving wood materials from environmental effects and providing long usage periods are economically important. If the wood materials are used without processing by preservative chemicals (with regard to the area of usage), fungal stains, insect infestation, humidity, fire etc. damage the wood. As a result of these damages, the woods require to be repaired, maintained or replaced before its economic life ends [1]. For this reason, in most places the wood materials should be impregnated with some chemicals. In the case of wood is not impregnated but only painted and varnished instead, the prevention on the surfaces is limited to a maximum of two years [2].

It is reported that, in mines, as a result of the impregnation of the beech and spruce wood with watersoluble salts, the bending, tens ile and impact strength decreased a little whereas compression strength increased [3]. In another research concerning the impregnation of pine, spruce, fir, beech and poplar woods with Antrasen, it was found that, the compression strength increased by 6-40\% and bending strength increased by $10-22 \%$ [4].

*Corresponding Author

e-mail: khakan@gazi.edu.tr

Digital Object Identifier (DOI) :
It was assessed that, salty impregnation materials increased the compression strength by 4.6-9.6\%, whereas decreased the bending strength by $2.9-16 \%$ [5]. In another study, chromate copper arsenate (CCA) and arsenate copper arsenate (ACA) salts did not cause any significant impact on modulus of elasticity in bending [6].

Impregnation of alder (Alnus glutinosa L.) with vinylmonomers increased the compression strength [7]. In another study, impregnation of Scotch pine and Oriental spruce with zinc clor and sulphate did not cause to a decrease in the compression strength [8].

In the interaction of wood material and impregnation period, the highest compression strength values were found in the samples impregnated with long-term dipping method whereas the lowest in the samples impregnated with shortterm dipping method. The compression strength in long-term dipping increased $11.4 \%$ in beech, $15.2 \%$ in oak, $21.6 \%$ in pine, $16.5 \%$ in spruce, $11.9 \%$ in fir and $12.3 \%$ in poplar. The amount of impregnation material penetrated into the wood cause to increase in compression strength [9].

In this study, Oriental beech, European oak, Black walnut, Lombardy poplar, Ash and Scotch pine woods 
commonly being used in furniture manufacturing and massive constructions were examined with respect to the effects of impregnation with Tanalith-E on the compression strength.

\section{MATERIAL AND METHOD}

\subsection{Material}

\subsubsection{Wood materials}

The Oriental beech (Fagus orientalis Lipsky), European oak (Quercus petraea Liebl.), Black walnut (Junglans nigra Lipsky), Lombardy poplar (Populus nigra Lipsky), Ash (Fraxinus exelsior Lipsky) and Scotch pine (Pinus sylvestris Lipsky) woods to be used as test sample was chosen randomly from the timber merchants in Ankara. Special emphasis is given for the selection of wood materials. Accordingly, non-deficient, proper, knotless, normally grown (without zone line, without reaction wood, without decay and insect mushroom damages) wood materials were selected.

\subsubsection{Impregnation material}

Tanalith-E, used as an impregnation material in this study was supplied from Hemel (Hemel-Hickson Timber Products Ldt.), Istanbul. Tanalith-E is not contain chromium or arsenic, non- flammable, fluent, waterbased, completely, soluble in water, non-corrosive material with a $\mathrm{pH}$ value of 7 and a density of $1.04 \mathrm{~g} . \mathrm{cm}^{-}$ ${ }^{3}$. It is available as a ready-made solution. Tanalith-E wood preservative contains a copper compound and azole biocides. Storage in a frost free environment is recommended [10].

\subsection{Method}

\subsubsection{Preparation of the test samples}

The rough drafts for the preparation test and control samples were cut from the sapwood parts of massive woods and conditioned at a temperature of $20 \pm 2{ }^{\circ} \mathrm{C}$ and $65 \pm 3 \%$ relative humidity for three months until reaching an equilibrium in humidity distribution. The samples for compression strength test, with a dimension of $20 \times 20 \times 30$ $\mathrm{mm}$ were cut from the drafts having an average humidity of $12 \%$ according to TS 2595 [11]. The densities and humidity values of all test samples were measured before the impregnation process. The test samples were impregnated by the method of the vacuum according to ASTM D 1413 [12], TS 344 [13] and TS 345 [14]. The specifications of the impregnation solution were determined before and after the process. The processes were carried out at $20 \pm 2{ }^{\circ} \mathrm{C}$ temperature. Retention of impregnation material $(R)$ was calculated by the formula;

$R=\frac{G . C}{V} 10^{3} \mathrm{~kg} \cdot \mathrm{m}^{-3} \quad G=T_{2}-T_{1}$

Where $G$ is the amount of impregnation solution absorbed by the sample $(\mathrm{g}), T_{2}$ is the sample weight after the impregnation $(\mathrm{g}), T_{1}$ is the sample weight before the impregnation $(\mathrm{g}), C$ is the concentration $(\%)$ of the impregnation solution and $V$ is the volume of the samples $\left(\mathrm{cm}^{3}\right)$.
Impregnated test samples were kept under a temperature of $20 \pm 2{ }^{\circ} \mathrm{C}$ and $65 \pm 3 \%$ relative humidity until they reach to a stable weight.

\subsubsection{Compression strength}

The tests for compression strength parallel to grains of wood materials were carried out with Universal Testing Machine shown in Figure 1, according to TS 2595. The capacity of Universal Testing Machine was $400 \mathrm{~N}$. The speed of testing machine was adjusted to $5 \mathrm{~mm} / \mathrm{min}$. for crashing to occur in 1-2 minutes.

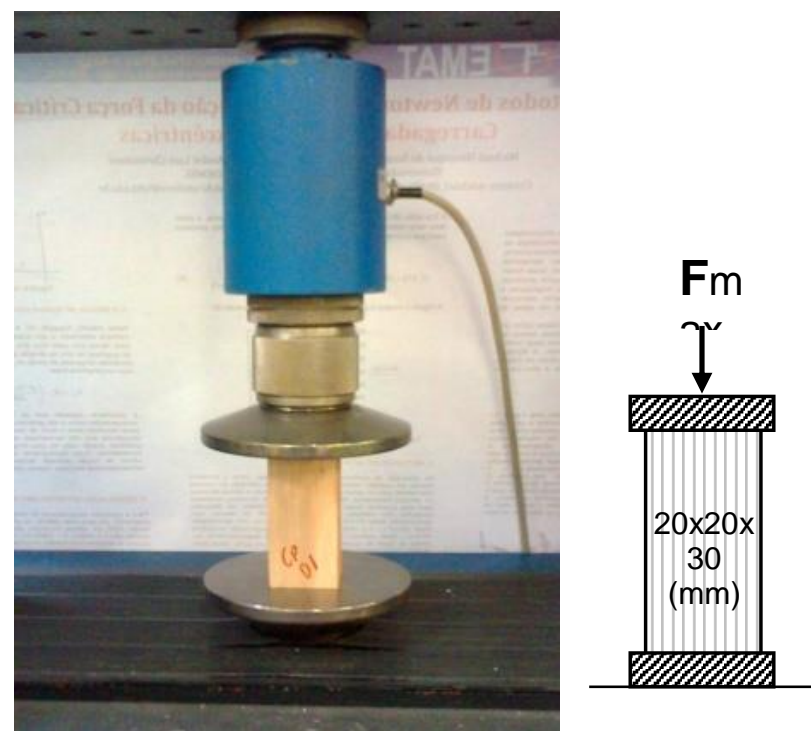

Figure 1.Compression strength test in a universal testing machine

Compression strength was calculated by the formula;

$\sigma_{b}=\frac{F_{\max }}{a b} N . \mathrm{mm}^{-2}$

Where $F_{\text {max }}$ is the breaking load on the scale $(\mathrm{N}), a$ is the cross-sectional width of test sample $(\mathrm{mm}), b$ is the crosssectional thickness of the test sample ( $\mathrm{mm})$.

\subsection{Data Analysis}

The results were analyzed statistically by computer software, SPSS 15.0 for Windows. A total of 24 treatment groups was obtained with 4 compression test sample and one control sample. Ten replications were made in each test group. Thus, a total of 120 samples $(6 \times 2 \times 10)$ were prepared. The effects of impregnation with Tanalith-E on compression strength of the woods were analyzed by ANOVA (Analysis of Variance). Duncan Test was also applied where appropriate.

\section{RESULTS AND DISCUSSION}

\subsection{Retention Amount}

Statistical values pertaining to averages of retention amount of experimented samples have been given in Table 1 . 
Table 1. Statistical values belong to averages of retention amount

\begin{tabular}{|c|c|c|c|c|c|c|}
\hline \multirow{2}{*}{ Statistical values } & \multicolumn{7}{|c|}{ WOOD MATERIALS } \\
\cline { 2 - 7 } & Beech & Oak & Walnut & Poplar & Ash & Pine \\
\hline $\mathrm{X}\left(\mathrm{kg} \cdot \mathrm{m}^{-3}\right)$ & 138.357 & 85.617 & 81.086 & 76.149 & 94.929 & 70.391 \\
\hline $\mathrm{Ss}\left(\mathrm{kg} \cdot \mathrm{m}^{-3}\right)$ & 5.46626 & 4.27868 & 2.03932 & 8.962018 & 3.1171408 & 4.55572 \\
\hline $\mathrm{v}\left(\mathrm{s}^{2}\right)$ & 33.2000 & 20.3412 & 4.62095 & 89.24197 & 10.796185 & 23.0607 \\
\hline $\min \left({\left.\mathrm{kg} . \mathrm{m}^{-3}\right)}^{\mathrm{m}}\right.$ & 129.481 & 76.348 & 79.035 & 66.356 & 90.032 & 62.348 \\
\hline $\mathrm{max}\left(\mathrm{kg} \cdot \mathrm{m}^{-3}\right)$ & 146.321 & 93.024 & 86.356 & 91.662 & 99.032 & 78.356 \\
\hline $\mathrm{N}$ & 10 & 10 & 10 & 10 & 10 & 10 \\
\hline
\end{tabular}

Table 2. Result of the retention amount variance analysis (ANOVA)

\begin{tabular}{|l|c|c|c|c|c|}
\hline $\begin{array}{c}\text { Variance } \\
\text { Source }\end{array}$ & Squares Sum & $\begin{array}{c}\text { Degree of } \\
\text { Exemption }\end{array}$ & $\begin{array}{c}\text { Averages of } \\
\text { Squares }\end{array}$ & F value & Sig. \\
\hline Inter Group & 30306 & 5 & 6061.246 & $200.636^{*}$ & 0.000 \\
\hline In-Group & 1631.351 & 54 & 30.210 & & \\
\hline TOTAL & 31937.58 & 59 & & & \\
\hline
\end{tabular}

$* \mathrm{P}<0.05$

According to $\mathrm{F}$ test which has been done to determine retention amount of wood materials; retention amounts have been differed from as per wood materials in statistical context $\left(\mathrm{F}_{(5 ; 54)}=200.636, \mathrm{P}<0.05\right)$. According to DUNCAN test results that are related to this (Table 3); highest retention amount has been obtained from oriental beech, then Ash, Oak, Black Walnut, Black Poplar, and Scotch Pine follow up, respectively. Mathematical difference between Oak and Black Tree has not been found relevant in statistical context. it, respectively. The main reason of the highest level of retention amount in Oriental beech may stem from high permeability ratio. In fact, in literature, retention amounts of wood materials which were impregnated by dipping method with Imersol-Aqua; on Oriental beech 274.728 $\mathrm{kg} \cdot \mathrm{m}^{-3}$ gained, and then on oak $44.936 \mathrm{~kg} \cdot \mathrm{m}^{-3}$, on Scotch pine $68.538 \mathrm{~kg} \cdot \mathrm{m}^{-3}$, on Uludag fir $79.180 \mathrm{~kg} \cdot \mathrm{m}^{-3}$, on spruce $92.225 \mathrm{~kg} . \mathrm{m}^{-3}$ and on Black Poplar $75.405 \mathrm{~kg} . \mathrm{m}^{-3}$ followed up, respectively [15].

Table 3. Retention amount related DUNCAN test result

\begin{tabular}{|l|c|c|c|c|c|c|}
\hline \multirow{2}{*}{\multicolumn{1}{c|}{ Groups }} & \multirow{2}{*}{$\mathrm{N}$} & \multicolumn{5}{c|}{ For sub-groups $\alpha=0,05$} \\
\cline { 3 - 7 } & & 1 & 2 & 3 & 4 & 5 \\
\hline Scotch Pine & 10 & 70.391 & & & & \\
\hline Poplar & 10 & & 76.149 & & & \\
\hline Walnut & 10 & & & 81.086 & & \\
\hline Oak & 10 & & & 85.617 & & \\
\hline Ash & 10 & & & & 94.929 & \\
\hline Beech & 10 & & & & & 138.357 \\
\hline \multicolumn{2}{|c|}{ SIGNIFICANT } & 1.000 & 1.000 & 10.071 & 1.000 & 1.000 \\
\hline
\end{tabular}

According to wood materials, the highest retention amount has been obtained from Oriental beech with 138.357 kg.m ${ }^{-3}$ and then Ash 94.929 kg.m ${ }^{-3}$, Oak 85.617 kg. ${ }^{-3}$, Black Walnut 81.086 kg.m ${ }^{-3}$, Black Poplar 76.149 $\mathrm{kg} \cdot \mathrm{m}^{-3}$ and Scotch Pine $70.391 \mathrm{~kg} \cdot \mathrm{m}^{-3}$ have followed up

\subsection{Compression Strength}

Statistical values of compression strength of impregnated wood materials and control samples have been given in Table 4. 
Table 4. Statistical values of compression strength

\begin{tabular}{|c|c|c|c|c|c|c|}
\hline \multirow{2}{*}{ Statistical values } & \multicolumn{6}{|c|}{ IMPREGNATED WOOD MATERIALS } \\
\hline & Beech & Oak & Walnut & Poplar & Ash & Pine \\
\hline $\mathrm{X}\left(N . m m^{-2}\right)$ & 66.771 & 62.748 & 59.638 & 37.758 & 69.676 & 54.207 \\
\hline Ss $\left(N . m m^{-2}\right)$ & 2.06912 & 2.41847 & 2.15121 & 2.20096 & 3.641582 & 1.63439 \\
\hline $\mathrm{v}\left(s^{2}\right)$ & 4.75698 & 6.49890 & 5.14192 & 5.38248 & 14.73458 & 2.96804 \\
\hline $\min \left(N . m m^{-2}\right)$ & 63.25 & 59.05 & 54.32 & 34.35 & 64.64 & 51.73 \\
\hline $\max \left(N . m m^{-2}\right)$ & 69.83 & 66.25 & 62.51 & 39.74 & 76.63 & 57.36 \\
\hline $\mathrm{N}$ & 10 & 10 & 10 & 10 & 10 & 10 \\
\hline \multicolumn{7}{|c|}{ UN-IMPREGNATED CONTROL SAMPLES } \\
\hline $\mathrm{X}\left(N . m m^{-2}\right)$ & 68.965 & 64.612 & 61.812 & 40.844 & 72.164 & 54.953 \\
\hline Ss $\left(N . m m^{-2}\right)$ & 2.52653 & 2.22249 & 3.07068 & 1.71388 & 4.246530 & 3.12027 \\
\hline $\mathrm{v}\left(s^{2}\right)$ & 7.09265 & 5.48830 & 10.4767 & 3.26378 & 20.03669 & 10.8179 \\
\hline $\min \left(N . m m^{-2}\right)$ & 64.82 & 60.12 & 56.35 & 38.03 & 62.34 & 50.03 \\
\hline $\max \left(N . m m^{-2}\right)$ & 73.25 & 68.62 & 69.03 & 44.35 & 78.35 & 59.03 \\
\hline $\mathrm{N}$ & 10 & 10 & 10 & 10 & 10 & 10 \\
\hline
\end{tabular}

According to $F$ Test which has been done for determination compression strength of impregnated wood materials (Table 5); compression strength values indicates significant differences according to type of wood material in statistical context $\left(\mathrm{F}_{(5 ; 54)}=200.990\right.$, $\mathrm{P}<0.05)$. According to Duncan test results which is related to this; the highest compression strength value has been obtained from Ash wood and then on Oriental beech, Oak, Walnut, Scotch Pine and Black Poplar followed up, respectively (Table 6).

According to $\mathrm{T}$ test which has been done to figure out compression strength of Impregnated massive wood material and un-impregnated control samples (Table 7); difference between compression strength have been determined significantly as 0.05 tolerance which is smaller than un-impregnated poplar samples. Mathematical differences in compression strength values between other wood materials have not been found significant.

Compression strength values parallel to grains of wood materials (control samples) which were not impregnated have not been found significant according to impregnated with Tanalith-E wood materials (except poplar) (Table 8 ). However on impregnated poplar wood, compression

Table 5. Compression strength variance analysis results

\begin{tabular}{|l|c|c|c|c|c|}
\hline $\begin{array}{c}\text { Variance } \\
\text { Source }\end{array}$ & Squares sum & $\begin{array}{c}\text { Degree of } \\
\text { exemption }\end{array}$ & $\begin{array}{c}\text { Averages of } \\
\text { Squares }\end{array}$ & F value & Sig. \\
\hline Inter Group & 6613.066 & 5 & 1322.613 & $200.990 *$ & 0.000 \\
\hline In-Group & 355.346 & 54 & 6.580 & & \\
\hline TOTAL & 6968.412 & 59 & & & \\
\hline
\end{tabular}

$* \mathrm{P}<0.05$

Table 6. Compression strength DUNCAN test's results

\begin{tabular}{|l|c|c|c|c|c|c|c|}
\hline \multirow{2}{*}{ GROUPS } & \multirow{2}{*}{$\mathrm{N}$} & \multicolumn{7}{c|}{ For sub-groups $\alpha=0,05$} \\
\cline { 3 - 8 } & & 1 & 2 & 3 & 4 & 5 & 6 \\
\hline Poplar & 10 & 37.758 & & & & & \\
\hline Pine & 10 & & 54.207 & & & & \\
\hline Walnut & 10 & & & 59.638 & & & \\
\hline Oak & 10 & & & & 62.748 & & \\
\hline Beech & 10 & & & & & 66.771 & \\
\hline Ash & 10 & & & & & & 69.676 \\
\hline \multicolumn{2}{|c|}{ SIGNIFICANT } & 1,000 & 1.000 & 1.000 & 1.000 & 1.000 & 1.000 \\
\hline
\end{tabular}


strength values were average $8.173 \%$ lower according

In Literature, Compression strength values parallel to to control samples. It may be the result of weakening

grains of massive wood materials were declared as

Table 7. Compression strength $\mathrm{T}$ test results

\begin{tabular}{|l|l|l|l|l|l|}
\hline WOODS & $\mathrm{N}$ & $\mathrm{X}$ & Ss & SD & SIG.(T)* \\
\hline Scotch Pine (E) & 10 & 54.207 & 1.7228 & 18 & $0.536^{\mathrm{NS}}$ \\
Scotch Pine (K) & 10 & 54.953 & 3.2891 & & \\
\hline Walnut (E) & 10 & 59.638 & 2.2676 & 18 & $0.099^{\mathrm{NS}}$ \\
Walnut (K) & 10 & 61.812 & 3.2368 & & \\
\hline Ash (E) & 10 & 69.676 & 3.8386 & 18 & $0.199^{\mathrm{NS}}$ \\
Ash (K) & 10 & 72.164 & 4.4762 & & \\
\hline Poplar (E) & 10 & 37.758 & 2.3200 & 18 & 0.004 \\
Poplar (K) & 10 & 40.844 & 1.8066 & & \\
\hline Beech (E) & 10 & 66.771 & 2.1811 & 18 & $0.06^{\mathrm{NS}}$ \\
Beech (K) & 10 & 68.965 & 2.6632 & & \\
\hline Oak (E) & 10 & 62.748 & 2.5493 & 18 & $0.106^{\mathrm{NS}}$ \\
Oak (K) & 10 & 64.612 & 2.3427 & & \\
\hline
\end{tabular}

$* \mathrm{P}<0.05, \mathrm{~N}$ : Number of samples X: Average, E: impregnated sample, K: Unimpregnated control sample, Ss:

Standard deviation, SD: Degree of exemption, NS (No significant)

effects of impregnation material on cohesion strength between poplar woods' grains.
Oriental beech 64.4 N.mm ${ }^{-2}$, Oak 65.5 N.mm ${ }^{-2}$, Scotch Pine 55.0 N.mm ${ }^{-2}$, Ash 50.4 N.mm ${ }^{-2}$, Black Walnut 72.0

Table 8. Compression strength differences of Impregnated and un-impregnated wood materials

\begin{tabular}{|l|r|r|r|r|r|r|}
\hline WOOD MATERIALS & \multicolumn{1}{c|}{ Beech } & \multicolumn{1}{c|}{ Oak } & \multicolumn{1}{c|}{ Walnut } & \multicolumn{1}{c|}{ Poplar } & \multicolumn{1}{c|}{ Ash } & \multicolumn{1}{c|}{ Pine } \\
\hline Impregnated (N.mm $\left.{ }^{-2}\right)$ & 66.771 & 62.748 & 59.638 & 37.758 & 69.676 & 54.207 \\
\hline Difference ratio (\%) & $3.285^{*}$ & $2.970^{*}$ & $3.645^{*}$ & 8.173 & $3.571^{*}$ & $1.376^{*}$ \\
\hline Un-impregnated (N.mm $\left.{ }^{-2}\right)$ & 68.965 & 64.612 & 61.812 & 40.844 & 72.164 & 54.953 \\
\hline
\end{tabular}

*NS (No significant): Difference is no significant according to T test

Compression strength has been obtained highest on ash N.mm ${ }^{-2}$, Black Poplar 34.5 N.mm ${ }^{-2}$ [1, 9]. These wood according to wood species and then Oriental beech, compression strength values except walnut and ash, the

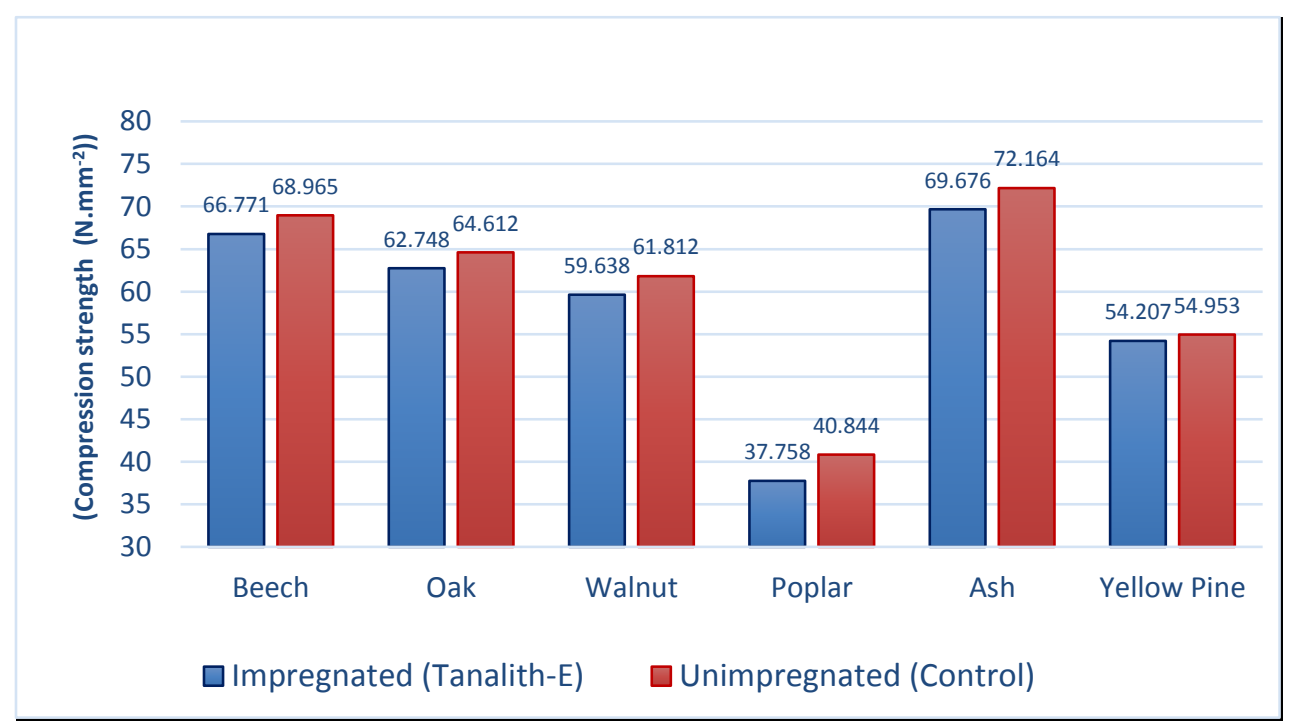

Figure 2. Compression strength values

Oak, Black Walnut, Scotch Pine, Black Poplar followed up, respectively (Figure 2). results came close to each other. However, difference between walnut and ash woods may stem from different 
features of geographical regions of tree samples and experiment samples.

\section{CONCLUSION}

The highest retention amounts in accordance with wood species were obtained from Oriental beech as 138.357 $\mathrm{kg} . \mathrm{m}^{-3}$, afterward, in Ash $94.929 \mathrm{~kg} . \mathrm{m}^{-3}$, in Oak 85.617 $\mathrm{kg} \cdot \mathrm{m}^{-3}$, in Black Walnut $81.086 \mathrm{~kg} \cdot \mathrm{m}^{-3}$, in Black Poplar $76.149 \mathrm{~kg} . \mathrm{m}^{-3}$ and in Scotch Pine $70.391 \mathrm{~kg} \cdot \mathrm{m}^{-3}$ followed up, respectively. The main reason for highest retention amount in Oriental beech may be the high level permeability of this kind of wood [15].

Compression strength values of impregnated wood materials founded in Oriental beech $66.771 \mathrm{~N} . \mathrm{mm}^{-2}$, in Oak 62.748 N.mm ${ }^{-2}$, in Black Walnut 59.638 N.mm ${ }^{-2}$, in Black Poplar 37.758 N.mm ${ }^{-2}$, in Ash 69.676 N.mm ${ }^{-2}$ and in Scotch Pine 54.207 N.mm ${ }^{-2}$. Compression strength values of control samples were determined as in Oriental beech 68.965 N.mm ${ }^{-2}$, in Oak 64.612 N.mm ${ }^{-2}$, in Black Walnut 61.812 N.mm ${ }^{-2}$, in Black Poplar 40.844 N.mm ${ }^{-2}$, in Ash 72.154 N.mm ${ }^{-2}$ and Scotch Pine 54.953 N.mm ${ }^{-2}$ respectively. According to $\mathrm{F}$ test which was carried out for Compression strengths of impregnated wood materials; compression strength values indicated significant differences in statistical meaning in accordance with wood species $\left(\mathrm{F}_{(5 ; 54)}=200.990, \mathrm{P}<0.05\right)$. According to DUNCAN test results which was carried out related this; the highest compression strength was obtained from ash wood, then oriental beech, Oak, Black Walnut, Scotch Pine and Black Poplar followed up, respectively. According to $\mathrm{T}$ test results which has been carried out to determine of diversities between compression strengths values of control samples and impregnated wood materials; distinction in Beech, Oak, Ash, Walnut, and Scotch Pine (except Poplar) was insignificant. In the case of impregnated Poplar wood, compression strength value was average $8.17 \%$ ratio lower in accordance with control samples. The reason can be reducing effect of impregnation material on cohesion strength between Poplar woods' grains. Results showed that impregnation material has negative effects only on Poplar wood, it has not any negative effect on beech, oak, ash, walnut and Scotch pine wood.

Accordingly, the highest values of compression strengths were obtained in impregnated Oriental beech and ash woods, whereas the lowest values were obtained in the Lombardy poplar wood. In consequence, in the massive construction and furniture elements that the compression strengths after the impregnation is of great concern, impregnation with Tanalith-E of beech and ash wood materials could be recommended.

\section{ACKNOWLEDGEMENT}

This study is a portion of the M.Sc. Thesis prepared by Nihat Dağlığlu, Institute of Science and Technology, Gazi University, Ankara, Turkey.

\section{REFERENCES}

1. Ors Y., Keskin H., “Ağaç Malzeme Teknolojisi”, Gazi Üniversitesi Yayın no: 2000/352, 1-6, 144-155, Gazi Kitabevi, Ankara (2008).

2. Atar M., "Effects of impregnation with imersol-aqua on the bending strength of some wood materials", Materials \& Design, 29(9): 1707-1712, (2008).

3. Kollman F., "Die eigenschaftanderung von gruben holz nach schutzsalzimpragnie-rung, Forschungsber", Des Landes Nordhrhein, Westfalen, Germany, 54: (1959).

4. Stabnikov V.M., "Puti uviliczenia sroka sluschby dreviesinyw konstrukcjach", Leningrad, 19-25, (1957).

5. Wazny J., "Investigations of the influence of wood preservatives on strength", Dreviesiny Sreda, 3: 181, (1973).

6. Bentsen B.A., "Mechanical properties of longleaf pine treated waterborne salt preservatives", USDA For Serv., 2: 434, (1984).

7. Temiz A., "Physcal and mechanical properties of woodpolymer composites prepared from alder wood (Alnus glutinosa Lipsky)", 32nd Annual Meeting Nara, Japan, (2001).

8. Tetjamer L., "Methoden und resultate der prufung schweizerischen bahnholzer, material pru fungsaf", schweizerischen polytechnikum.Zurich: Paul Paray Verlac, (1986).

9. Keskin H., Atar M., Togay A., "Impacts of impregnation with imersol-aqua on the compression strength of some solid wood materials", Construction and Building Materials, 22(7): 1402-1408, (2008).

10. Hemel-Hickson's Timber Impregnation Co. (GB), Into the 21st. century, "Imersol-Aqua brochure", Datasheet, 4(2): 6214, (2000).

11. TS 2595, "Odunun Liflere Paralel Doğrultuda Basınç Dayanımının Tayini”, TSE, Ankara (1977).

12. ASTM D 1413-76, "Standard Test Method of Testing Wood Preservatives by Laboratory Soil Blocks Cultures", ASTM Standards, USA, (1976).

13. TS 344, “Ahşap Koruma Genel Kuralları", TSE, Ankara, (1981).

14. TS 345, “Ahşap Emprenye Maddeleri Etkilerinin Muayene Metotları, TSE, Ankara, (1974).

15. Ors Y., Atar M., Keskin, H., Yavuzcan H.G., "Impacts of impregnation with imersol-aqua on the modulus of elasticity in bending", Journal of Applied Polymer Science, 99(6): 3210, (2006). 